\title{
Monitoring a Pre-Normative Multi-Family Housing Case-Study in a Mediterranean Climate
}

\author{
Teresa Blázquez de Pineda, Rafael Suárez* and Juan José Sendra Salas \\ Instituto Universitario de Arquitectura y Ciencias de la Construcción, Escuela Técnica Superior de Arquitectura, \\ Universidad de Sevilla, Av. de Reina Mercedes, 2, 41012 Sevilla, Spain; tblazquez@us.es (T.B.d.P.); \\ jsendra@us.es (J.J.S.S.); \\ * Correspondence: rsuarez@us.es; Tel.: +34-954-559-517
}

Academic Editor: Cinzia Buratti

Received: 19 September 2016; Accepted: 15 December 2016; Published: 23 December 2016

\begin{abstract}
In Spain, a significant percentage of the residential building stock presents deficient indoor conditions regarding current energy standards, due to having been constructed before the Norma Básica de la Edificación in 1979 (NBE CT 79) regarding thermal conditions in buildings. Current environmental policies pursue a cut in energy consumption and seek improvements in indoor conditions by refurbishing current stock, mainly that constructed between 1950 and 1980. Before any retrofitting action, housing monitoring has become essential for a better understanding of real and passive environmental behavior. This paper aims to present the monitoring in hourly intervals, real-time and post-occupancy conditions of a residential building in Seville, built in the 1950s and belonging to national heritage. The results obtained show major discrepancies between thermal indoor data collected and comfort conditions, both in summer and winter, which are solved by the sporadic use of cooling and heating devices present in the dwellings, thus leading to less energy consumption than expected. This is a common occurrence in multi-family housing units from the Mediterranean arc: there are many periods of the year in which a vast number of the population lives in poor energy conditions.
\end{abstract}

Keywords: monitoring; energy refurbishment; energy demand; adaptive comfort

\section{Introduction}

The current housing stock is responsible for almost $40 \%$ of the global amount of energy used in the European Union and a third of $\mathrm{CO}_{2}$ emissions. Sixty-one percent of the existing Spanish residential stock [1] was built before the first mandatory regulation on thermal conditions in buildings NBE-CT 79 [2]. This code was supposed to be applied to every new construction, regardless of the final use. Limitations concerning U-values of the thermal envelope, depending on the different climate zones, were established, except for the windows. Moreover, the global heat transmission coefficient of buildings was also defined; this relies on the building's compactness and the energy system used for heating.

The transposition of Directive 2002/91/CE motivated a legislative change through the establishment of the Basic Document on Energy Saving from the Spanish Technical Building Code (CTE DB-HE1). This document provided new requirements for the building's thermal envelope, by limiting U-values for the opaque elements and for the transparent elements and stating limitations for the modified solar factor of the windows. Subsequently, due to the modifications driven by Directive 2010/31/UE, the Basic Document on Energy Saving, DB-HE1 2013, was updated in order to comply with the aims of Horizon 2020.

Previous existing housing stock failed to comply due to insufficient thermal insulation in buildings' envelopes. This indicates deficient environmental behavior regarding present energy standards, 
which results in an excess in energy consumption and $\mathrm{CO}_{2}$ emissions for the maintenance of a minimum level of indoor comfort and habitability in the dwellings. Hence, European [3] and Spanish [4] energy policies treat the retrofitting of existing building stock as a major issue, especially concerning housing due to its potential for improvement.

Current residential stock has already been the focus of several studies related to its environmental performance thanks to its potential in energy savings. These studies: examine classification methods of the housing stock; study in situ data collection by monitoring environmental parameters and electricity consumption; analyze the composition of thermal envelopes and carry out research into the impact of user behavior on the energy and environmental performance of a dwelling. The classification and characterization of building facades [5] and typologies [6] has enabled the analysis of the existent casuistry and their knowledge; therefore, the constructive system that belongs to a city, a region or a country can be represented, and useful tools have been developed that can be used to seek and propose the optimal retrofitting solutions that are suitable for each case [7]. The proposal of standard solutions and their applications has also been analyzed in several studies, at a national level in the Spanish residential stock [8], as well as in other international locations [9-12], under various environmental and climate conditions. These aspects have an impact on the energy performance of buildings, and therefore, there is a need to establish similar guidelines to intervene in buildings that share the same climate zones at the European level [13]. Retrofitting strategies that aim to revise the state of the art of passive cooling and thermal dissipation in existing buildings and their contributions towards improvements in indoor air quality and the reduction of energy demand have also been considered as suitable for implementation to resolve the deficiencies in this social housing stock [14,15].

The acknowledgement of the current state of these residential buildings constitutes a key element when considering any kind of intervention in buildings. There is a shortage of information on environmental variables and on energy demand extracted from field tests undertaken in real use and operative conditions, especially in Mediterranean areas. In spite of a number of remarkable exceptions [16-19], the majority of results are based on energy simulations under standard use and operative conditions [20]. In most cases, mainly related to social housing in the Mediterranean climate, the results turn out to be very far from reality [21].

The aim of this work is to present the monitoring campaign of a case-study dwelling in a multi-family building under Mediterranean weather conditions and to highlight it as a basic issue when studying the real energy behavior of the building as a previous step to its retrofitting intervention. Monitoring allows not only the in situ assessment of the building's hygrothermal behavior in its current state and the establishment of its relationship to indoor comfort conditions, but also the calibration of the generated energy models [22-24]. The former becomes an indicator of its degree of obsolescence from an environmental and energy angle, while the latter makes it possible to evaluate retrofitting strategies in the case study.

This study forms part of a research project based on the environmental and energy assessment of multi-familiar dwellings in the Mediterranean climate and on the proposal of retrofitting strategies concerning the openings.

This paper aims to present and analyze the results of a monitoring campaign, undertaken for the duration of a year of a dwelling from a multi-family building, located in a neighborhood of national heritage, which was built in Seville in the 1950s. Data recording has been carried out in 30-min intervals, with data loggers that record air temperature, relative humidity, pressure, dew point, wind direction and speed. An annual database with environmental variables measured both indoors and in the adjacent surroundings of the building is obtained.

\section{Case Study}

The case-study building lies within a group of dwellings named "La Estrella", which encloses 432 housing units, commercial premises and storage rooms (Figure 1). This building was constructed between 1955 and 1963 in Seville by the Medina Benjumea brothers, members of the "OTAISA" 
emblematic group of architects. It is included in the Docomomo Ibérico database [25] and the Andalusian Heritage Building database [26] with Registration Number 01410910216.

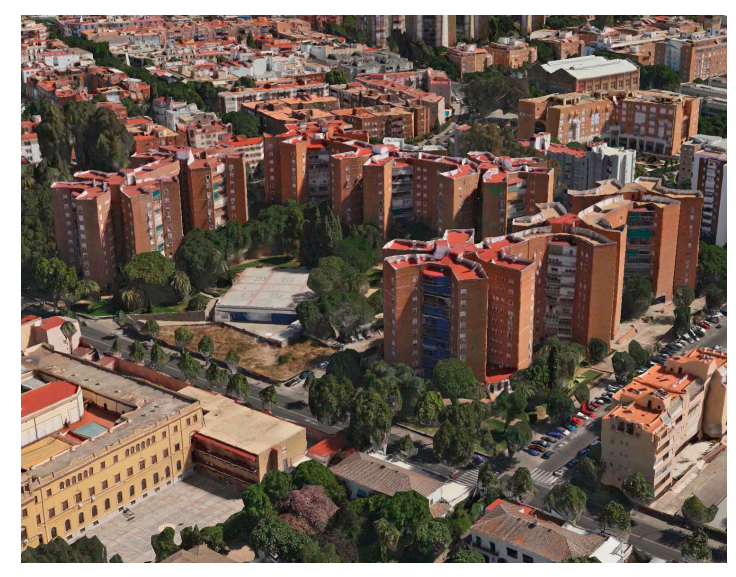

Figure 1. Bird's eye view of residential complex La Estrella.

The star-shaped towers reinterpret the " $\mathrm{H}$ " block typology (Figure 2): the three wings connected by a vertical communication core offer a wide variety of orientations, while the double corridor eases indoor ventilation. The buildings have an accessible inverted roof and a double-layer brick facade with an intermediate air chamber as its envelope solution, which was an improvement on the widespread

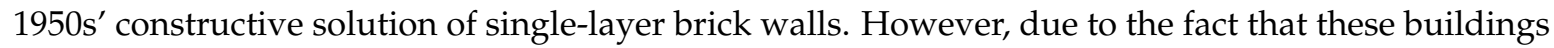
were constructed before the NBE-CT-79 mandatory regulation on thermal conditions in buildings, no kind of thermal insulation is present.

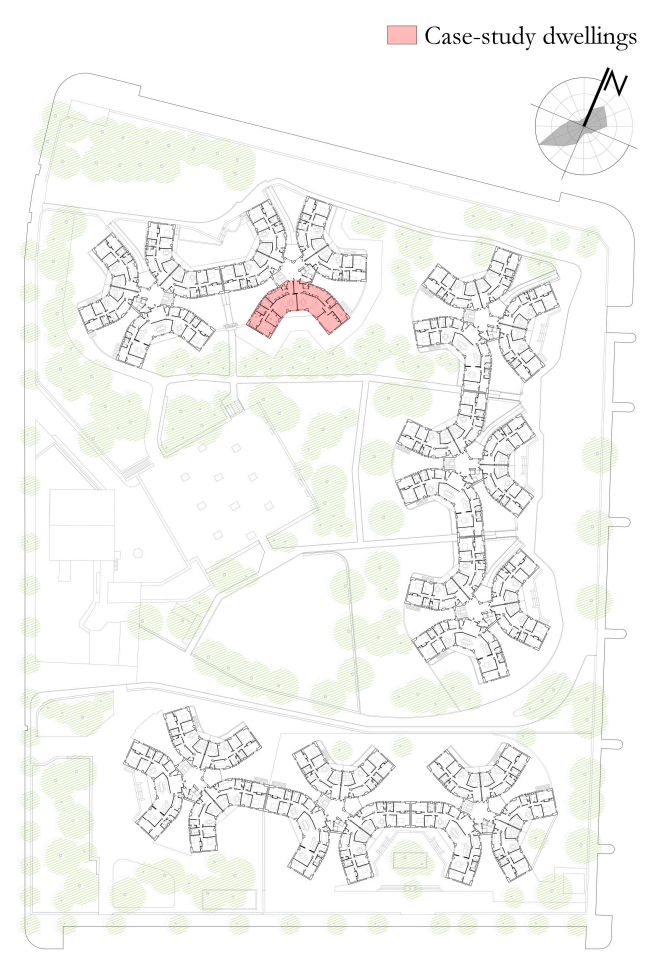

Figure 2. Plan of the residential complex with monitored dwellings and prevailing winds.

In order to run the monitoring campaign under real use and operational conditions and to record environmental parameters, two dwellings located on the first floor in Block 2 were selected. 
Each dwelling accounts for an approximate surface of $100 \mathrm{~m}^{2}$, with a southeast orientation in Flat $A$ and a south orientation in Flat B (Figures 3 and 4). The rooms that have been monitored in each dwelling are the bedroom (DVA in flat A; DVB in flat B) and the living-room (SVA in flat A; SVB in flat B).

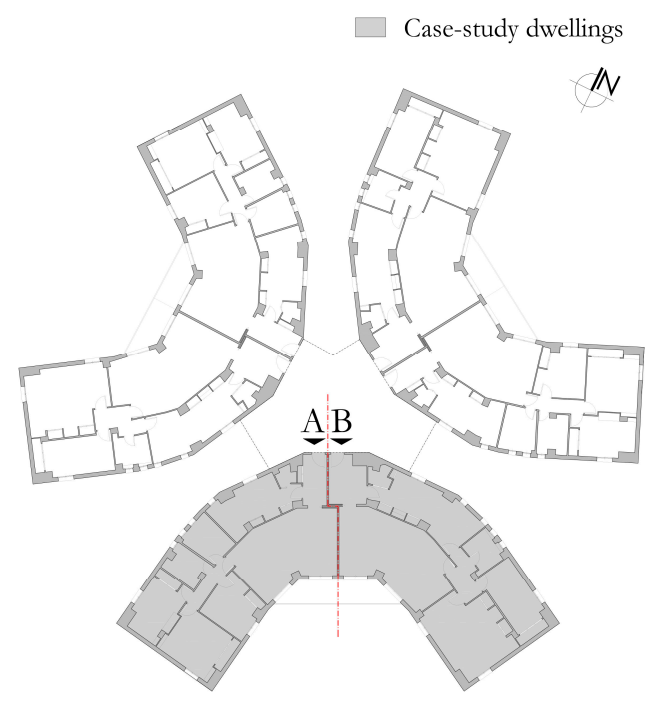

Figure 3. Floor plan with monitored dwellings.

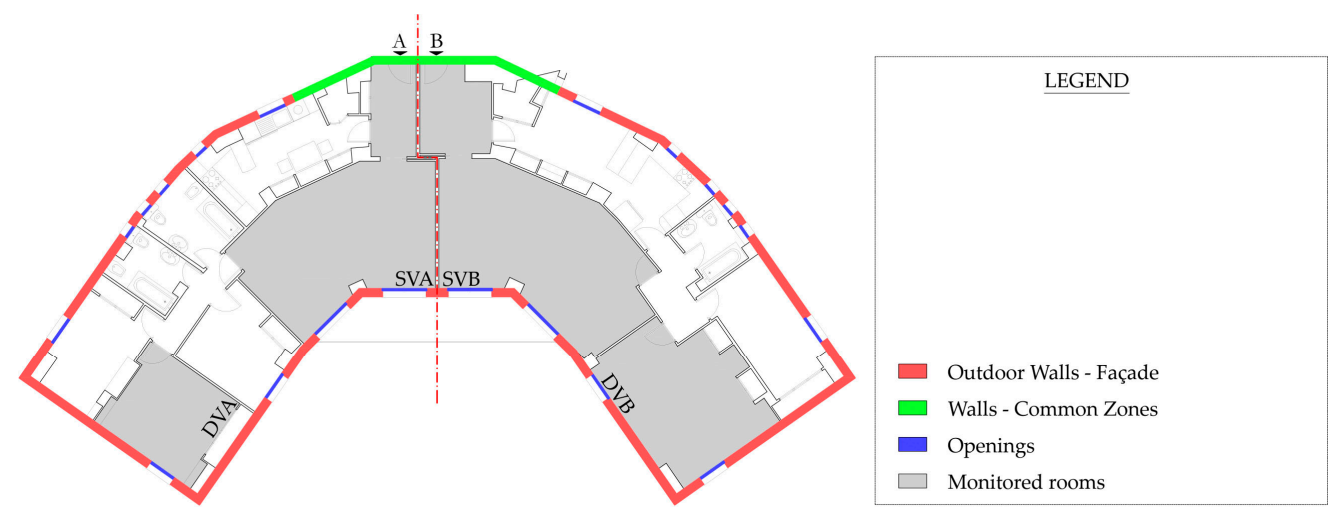

Figure 4. Thermal envelope definition.

The selected dwellings have largely remained as originally built in terms of indoor distribution and thermal envelope; however, in 1984, steel window frames were replaced by others of anodized aluminum without any thermal bridge break, with approximately $4-6 \mathrm{~mm}$ single glazing. Today, these single-glazed windows remain in Dwelling B, while Dwelling A's windows were updated in 1996 to incorporate 6-6-6 $\mathrm{mm}$ double glazing.

There is a further issue to consider regarding the energy performance of the envelope, which is the existence of blind boxes in the bedroom windows. In terms of energy performance, they act as highly ventilated air chambers and facilitate air filtrations. In the selected dwellings, only the bedroom windows feature these boxes.

In order to assess the energy behavior of the walls, transmittance values have been calculated [27] (Table 1). Appendix D from “CTE DB-HE1 2013" [28] has been taken as a reference to determine their discrepancies from Spanish regulation energy-demand limitations. To this end, Seville's climate zone should be considered according to the Spanish regulation. Spanish climate zones are labelled with a letter, from A-E, which corresponds to an increasing scale of winter climate severity, and a number, from 1-4, for an increasing scale of summer climate severity. In this case, Seville is in the B4 climate 
zone, with Mediterranean weather conditions, where summers can reach very high temperatures (over $40^{\circ} \mathrm{C}$ ) and where the region enjoys mild winters. The subsequent comparative analysis shows the degree of influence exerted by the lack of thermal insulation in the buildings. As a result, the wall transmittance is double that of the maximum value established by the aforementioned regulation, which has an immediate effect on increasing energy gains and losses in the dwellings.

To evaluate the openings, the following parameters have been calculated: transmittance value for the glass $\left(\mathrm{U}_{\mathrm{g}}\right)$, transmittance value for the frame $\left(\mathrm{U}_{\mathrm{f}}\right)$, transmittance value for the opening $\left(\mathrm{U}_{\mathrm{W}}\right)$ percentage of surface of each element of the window $(\%)$, solar factor of the glass ( $\mathrm{g}$ ), frame factor (FM) and solar absorptivity. The same comparative analysis of the parameters as that of the walls has been carried out, whereby each orientation is considered and bedroom openings are differentiated from those in the living-rooms. Regarding the existent solution of the openings (made of metallic frame with no thermal bridge breaks and either single or double glazing), two transmittance values have been obtained for bedroom openings, with a frame factor of 0.26 , and another two values for the living-room openings, with a frame factor of 0.17. Calculated transmittance values have been compared to the limit values $\left(\mathrm{U}_{\mathrm{lim}}\right)$ established by Spanish regulation [29], regarding each orientation and opening percentage in the facades. Concerning the different orientations of the openings in Dwelling A, the opening in the bedroom has a south orientation, while that in the living-room has a southeast orientation. In Dwelling B, the opening in the bedroom has a south and southeast orientation, while that in the living-room also has a southeast orientation. For both dwellings, the opening percentage in facades stands at approximately $5 \%$ in the facade of the bedrooms and $18 \%$ in that of the living-rooms.

Table 1 shows that single-glazing openings have a very close-fitting transmittance value to the limit established for Climate Zone B4, according to the Spanish regulation (DB-HE1) [29], when the opening percentage in facades is under $10 \%$, and that major differences only exist when comparing north-orientation openings. When the opening percentage in facades is between $11 \%$ and $20 \%$, single-glazing openings exceed the limit values in north, east and west orientations. However, double-glazing openings present a transmittance value closer to the established limit values, thereby perfectly meeting the aforementioned regulation limit values in every orientation in both dwellings.

Table 1. Thermal envelope definition of monitored dwellings. U-values and limit U-values according to the Spanish regulation (DB-HE1) [29].

\begin{tabular}{|c|c|c|c|}
\hline & Building Envelope & $\mathrm{U} *\left(\mathrm{~W} / \mathrm{m}^{2} \mathrm{~K}\right)$ & $\mathrm{U}_{\mathrm{lim}}\left(\mathrm{W} / \mathrm{m}^{2} \mathrm{~K}\right)$ \\
\hline \multicolumn{2}{|c|}{ Brick-faced wall, air chamber and hollow brick plastered partition } & $\mathrm{U}_{\mathrm{e}}=1.57$ & $\mathrm{U}_{\text {elim }}=0.82$ \\
\hline \multicolumn{2}{|r|}{ Floors } & $\mathrm{U}_{\mathrm{F}}=1.96$ & $\mathrm{U}_{\text {Flim }}=0.52$ \\
\hline \multicolumn{2}{|c|}{ Hollow brick plastered wall (connected to common areas) } & $\mathrm{U}_{\mathrm{e}}=1.85$ & $\mathrm{U}_{\text {elim }}=0.82$ \\
\hline \multirow{3}{*}{$\begin{array}{c}\text { Bedroom } \\
\text { (5\% openings) }\end{array}$} & \multirow{2}{*}{ Double-glazing 6-6-6 mm. Metal frame (no T.B. **) } & \multirow{2}{*}{$\mathrm{U}_{\mathrm{W}}=3.9$} & $\mathrm{U}_{\mathrm{Wlim}, \mathrm{N}, \mathrm{NE}, \mathrm{NW}}=5.4$ \\
\hline & & & $\mathrm{U}_{\mathrm{Wlim}, \mathrm{E}, \mathrm{W}}=5.7$ \\
\hline & Single-glazing 4-6 mm. Metal frame (no T.B. ${ }^{* *}$ ) & $\mathrm{U}_{\mathrm{W}}=5.70$ & $\mathrm{U}_{\mathrm{Wlim}, \mathrm{S}, \mathrm{SE}, \mathrm{SW}}=5.7$ \\
\hline \multirow{3}{*}{$\begin{array}{l}\text { Living-room } \\
\text { (18\% openings) }\end{array}$} & \multirow{2}{*}{ Double-glazing 6-6-6 mm. Metal frame (no T.B. ${ }^{* *}$ ) } & \multirow{2}{*}{$\mathrm{U}_{\mathrm{W}}=3.7$} & $\mathrm{U}_{\mathrm{Wlim}, \mathrm{N}, \mathrm{NE}, \mathrm{NW}}=3.8$ \\
\hline & & & $\mathrm{U}_{\mathrm{Wlim}, \mathrm{E}, \mathrm{W}}=4.9$ \\
\hline & Single-glazing 4-6 mm. Metal frame (no T.B. ${ }^{* *}$ ) & $\mathrm{U}_{\mathrm{W}}=5.70$ & $\mathrm{U}_{\mathrm{Wlim}, \mathrm{S}, \mathrm{SE}, \mathrm{SW}}=5.7$ \\
\hline
\end{tabular}

${ }^{*} \mathrm{U}_{\mathrm{e}}=\mathrm{U}$-value for walls; $\mathrm{U}_{\mathrm{F}}=\mathrm{U}$-value for floors; $\mathrm{U}_{\mathrm{W}}=\mathrm{U}$-value for openings; ${ }^{* *}$ T.B. = thermal bridge break.

In general, collective housing buildings in the Mediterranean area seldom feature air-conditioning systems (heating and/or cooling) or centralized systems for the whole building or single dwellings. As in most of the cases in this region, a split heat pump and a small heater are found in the living-room, which are sporadically used in high temperature situations in summer and in very cold temperature situations in winter. An electric radiator is the single electric device found in the bedroom, which is only used on the coldest days in winter. The monitoring results clearly show sharp increases or decreases of indoor temperature that account for those critical moments at which the user switches 
on this equipment. Neither mechanical nor hybrid ventilation is present in the dwellings. Bathroom shunts are currently sealed.

\section{Methodology}

The case-study dwellings have undergone an energy assessment according to the methodology carried out in similar work of the research group TEP-130 of the University of Seville [29].

The objective of the monitoring campaign is to register environmental indoor data in order to carry out an analysis to observe how indoor measured parameters unfold over time. The monitoring period began on 1 April 2013 and finished on 31 March 2014. A daily data record was made at 30 -min intervals, resulting in a total of 563,328 entries. Monitoring was undertaken following the ISO 7726:1998 protocol [30]. This international rule both specifies the minimum requirements of the use of instruments to measure physical parameters related to environmental conditions and explains the measurement methods. The main aim of this set of regulations is not the determination of a global comfort index, but the standardization of the registration process of environmental data that can be later used to determine these values.

Data registration was performed using four data loggers (Figure 5). One of these loggers is named the master, and it is in charge of the weather station located outdoors. The devices have a memory capacity of 75 days; therefore, data have to be periodically transferred to a laptop by USB connection. On the application of the Easy Weather program (a communications and monitoring software tool), data are readily translated into a tabulated text format, in order to ease data treatment using a data processor software tool (Microsoft Excel v. 2013). Data loggers may be manipulated by a touch-screen or by using the Easy Weather software tool.

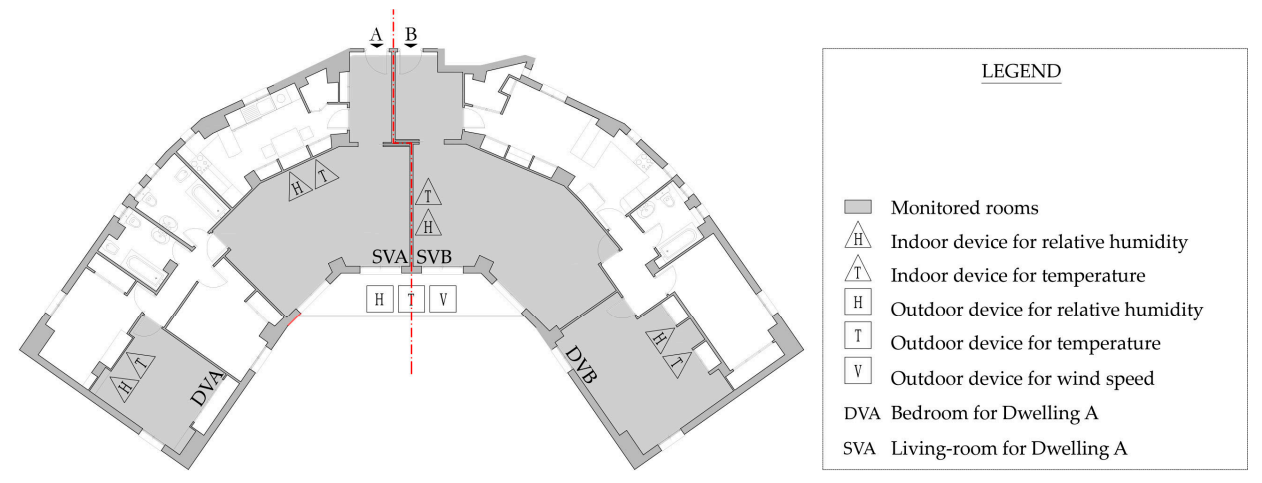

Figure 5. Distribution of the monitoring devices.

Amongst the different variables registered indoors, air temperature and relative humidity have been recorded by means of two separate sounding lines located in the living-room (day zone) and in the bedroom (night zone) in each dwelling. A weather station located on the outdoor balcony completes the whole system. The weather station is protected from solar radiation and is south oriented (Figure 6) (Table 2). Outdoor air temperature, relative humidity, wind direction and speed are registered with this device.

Table 2. Summary of installed devices in the monitored dwellings.

\begin{tabular}{cccccc}
\hline $\begin{array}{c}\text { Devices } \\
\text { (Indoor/Outdoor) }\end{array}$ & $\begin{array}{c}\text { Weather } \\
\text { Station }\end{array}$ & $\begin{array}{c}\text { Bedroom } \\
\text { Dwelling A }\end{array}$ & $\begin{array}{c}\text { Living-Room } \\
\text { Dwelling A }\end{array}$ & $\begin{array}{c}\text { Bedroom } \\
\text { Dwelling B }\end{array}$ & $\begin{array}{c}\text { Living-Room } \\
\text { Dwelling B }\end{array}$ \\
\hline Air temperature & 1 & 1 & 1 & 1 & 1 \\
Wind speed and direction & 1 & 0 & 0 & 0 & 0 \\
Relative humidity & 1 & 1 & 1 & 1 & 1 \\
Total & 3 & 2 & 2 & 2 & 2 \\
\hline
\end{tabular}




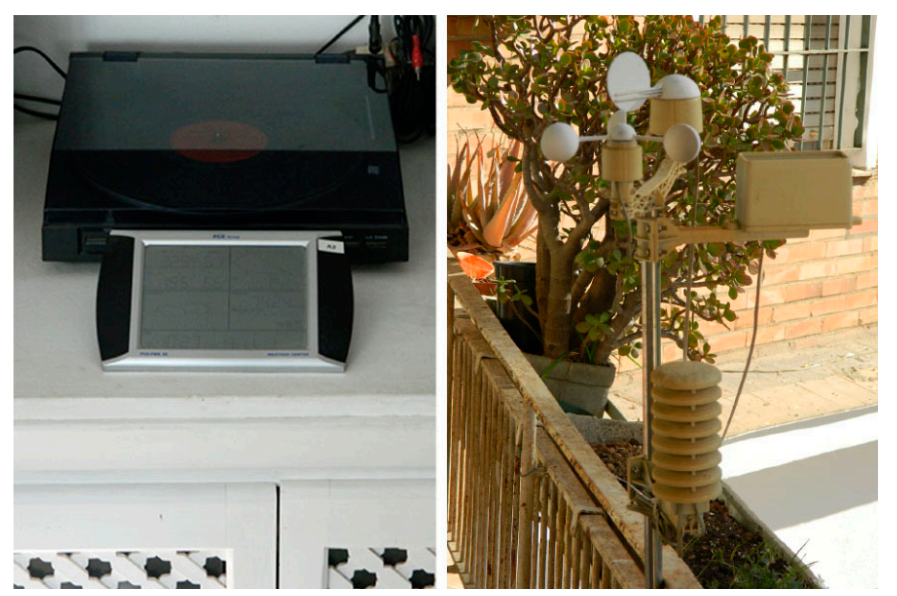

Figure 6. Indoor data logger and outdoor weather station.

A pressurization and depressurization test has been carried out in the monitored dwellings in order to complement the analysis of the results obtained. Air-tightness has been measured using blower-door equipment, in accordance with the ISO 9972:2015 protocol [31]. Additionally, a thermography analysis of the building envelope has also been carried out, with the aim of identifying air-leak points and thermal bridges and to ascertain the level of thermal homogeneity that the external walls offer. From the pictures in Figure 7, the fairly weak points concerning thermal losses can be observed in the upper part of the window where a blind box is located, which acts as a highly ventilated air chamber. Clear differences of temperature of the blind box and the window surroundings can clearly be determined from the indoor thermography. This blind box can easily be identified from outdoors, as well as the framework's edge, both therefore indicating a thermal bridge (Figure 7).

Table 3 offers infiltration rates in the two dwellings at 50 Pa pressure, as well as its estimation in atmospheric pressure. Global results for the whole monitored housing units offer a value of 0.36 air change per hour ( $\mathrm{ACH}$ ) in Dwelling A and a 0.48 ACH in Dwelling B, which are fairly high levels of air-tightness. The fact that ventilation shunts are sealed must be borne in mind, since this notably increases these results. However, these values are inferior to those established by Spanish regulation (DB-HS3) (Table 3), which means that the dwellings are not well ventilated. Ventilation needs to be performed by opening the windows, leading to more uncontrolled energy losses in summer and winter.

In a more detailed approach to the monitored rooms of Dwelling A, the results in Table 3 show that the infiltration rate in the bedroom is of $0.54 \mathrm{ACH}$, most of which occurs through the blind box. Since the living-room window has no blinds, the infiltration rate in this case is lower, at $0.23 \mathrm{ACH}$.

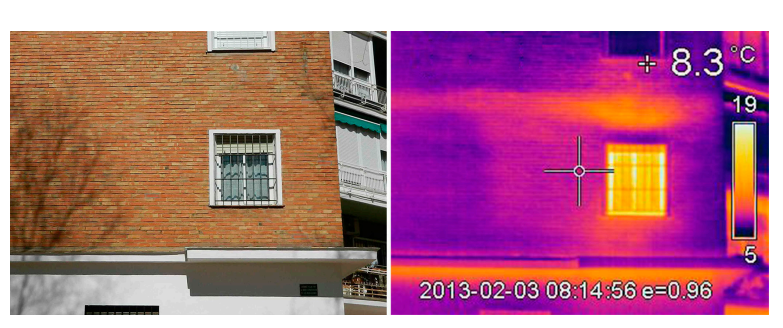

(a)
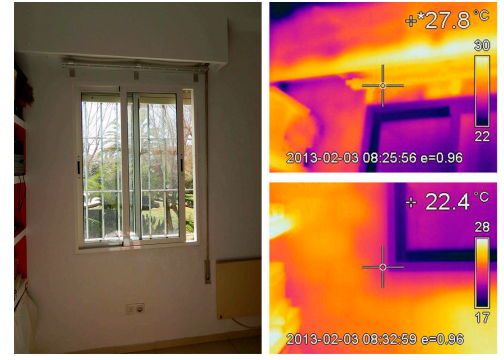

(b)

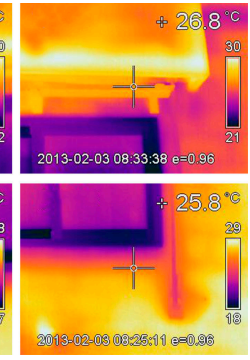

Figure 7. Dwelling A, bedroom window thermographs: (a) outdoors; (b) indoors. 
Table 3. Air-tightness test results. ACH, air change per hour.

\begin{tabular}{|c|c|c|c|}
\hline Room Unit & $\begin{array}{l}\text { Infiltration Rate at } \\
50 \mathrm{~Pa}\left(\mathrm{n} 50^{*}\right)(\mathrm{ACH})\end{array}$ & $\begin{array}{c}\text { Infiltration Rate at } \\
\text { Atmospheric Pressure (ACH) }\end{array}$ & $\begin{array}{c}\text { Desired Ventilation Rate } \\
\text { According to CTE DB-HS3 (ACH) }\end{array}$ \\
\hline Dwelling A & 6.9 & 0.36 & 0.84 \\
\hline Living-room SVA & 3.8 & 0.23 & - \\
\hline Bedroom DVA & 9.0 & 0.54 & - \\
\hline Blinds DVA & 5.2 & 0.31 & - \\
\hline Dwelling B & 8.6 & 0.48 & 0.68 \\
\hline Living-room SVB & 5.4 & 0.30 & - \\
\hline
\end{tabular}

\section{Results}

Once the monitoring campaign is completed, then the thermal behavior of the dwellings is analyzed, and the way in which the different temperature and relative humidity indoor and outdoor parameters unfold over time is assessed.

In order to carry out an assessment of indoor comfort conditions, indoor temperature values have been compared to a comfort band in line with the ASHRAE methodology, by applying the adaptive comfort equation [32]. In order to calculate the comfort band, a $90 \%$ level of acceptance has been considered, included in a $\pm 2.5^{\circ} \mathrm{C}$ interval. According to this equation, $90 \%$ of occupants would be satisfied within established conditions of the comfort band.

\subsection{Outdoor Temperature}

In order to analyze the evolution of the monitored outdoor temperature, weather data from the Spanish Weather for Energy Calculations (SWEC) database [33] are used. Values from a variety of environmental parameters have been gathered on an hourly basis for the past 20 years in the weather station of San Pablo airport, in Seville. The graph shows that average monthly outdoor temperature values recorded in situ are superior to the values from the database in the spring and summer seasons, while these values from the monitoring campaign decrease in autumn, to eventually increase in winter to a higher temperature trend than that of the database values (Figure 8).

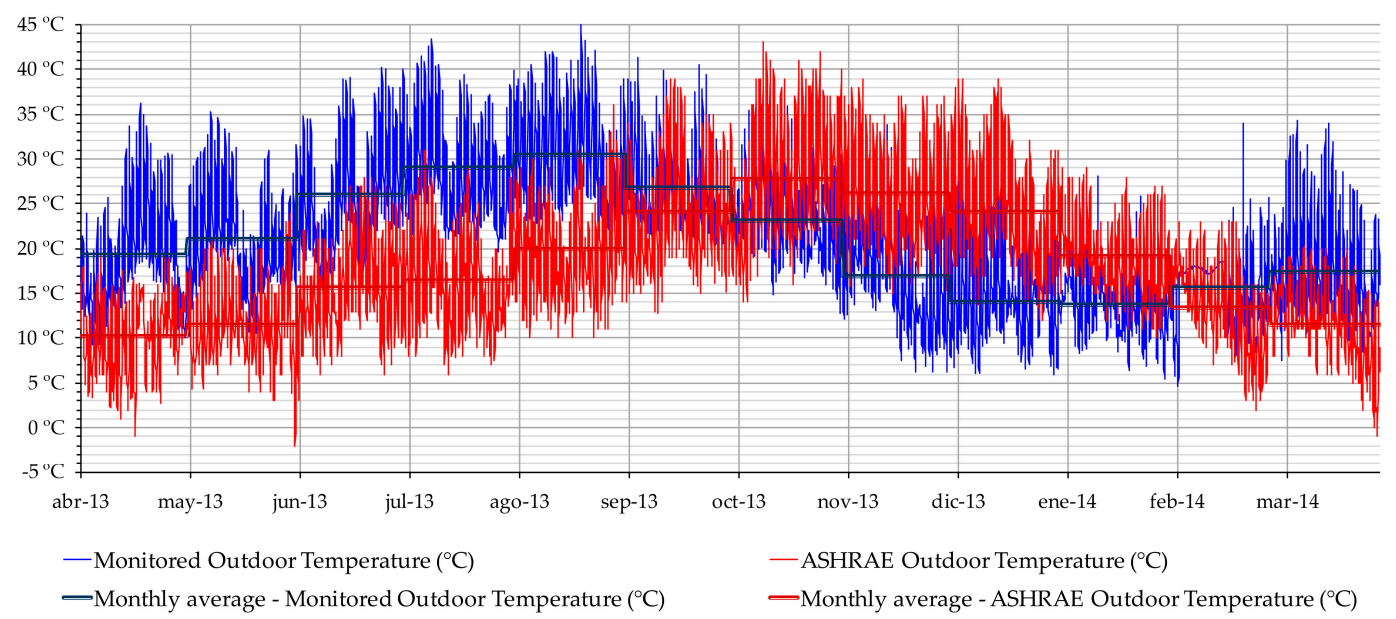

Figure 8. Monitored and registered daily outdoor temperature and average outdoor temperature.

\subsection{Indoor Temperature}

An indoor temperature analysis has been carried out that differentiates between each dwelling (A and B), as well as between the rooms analyzed in each housing unit: bedroom (DV) and living-room (SV). In this paper, results obtained in each monitored room of Dwelling A are shown: bedroom DVA 
and living-room SVA. In order to ascertain how climate conditions within the dwelling are managed in each season of the year, a monthly record of indoor temperatures in the monitored rooms of Dwelling A is analyzed for the months of April (mid-season), July (summer) and January (winter), following the monitoring campaign's order (Figure 9).

From the monthly records, it can be observed that indoor environmental behavior in each unit is largely homogeneous. In the B4 climate zone, mid-season months, such as March, April, May, October and, partly, November, show very stable indoor temperature values that stay between the comfort band limits most of the time, while outdoor temperature values may reach significant oscillations. In this case, in the mid-season record, values are between the comfort band limits for half the month. In contrast, winter and summer weather conditions directly affect indoor temperature values, leading to excessive cooling in the dwelling in the cold season and overheating situations in the hot season (Figure 9).
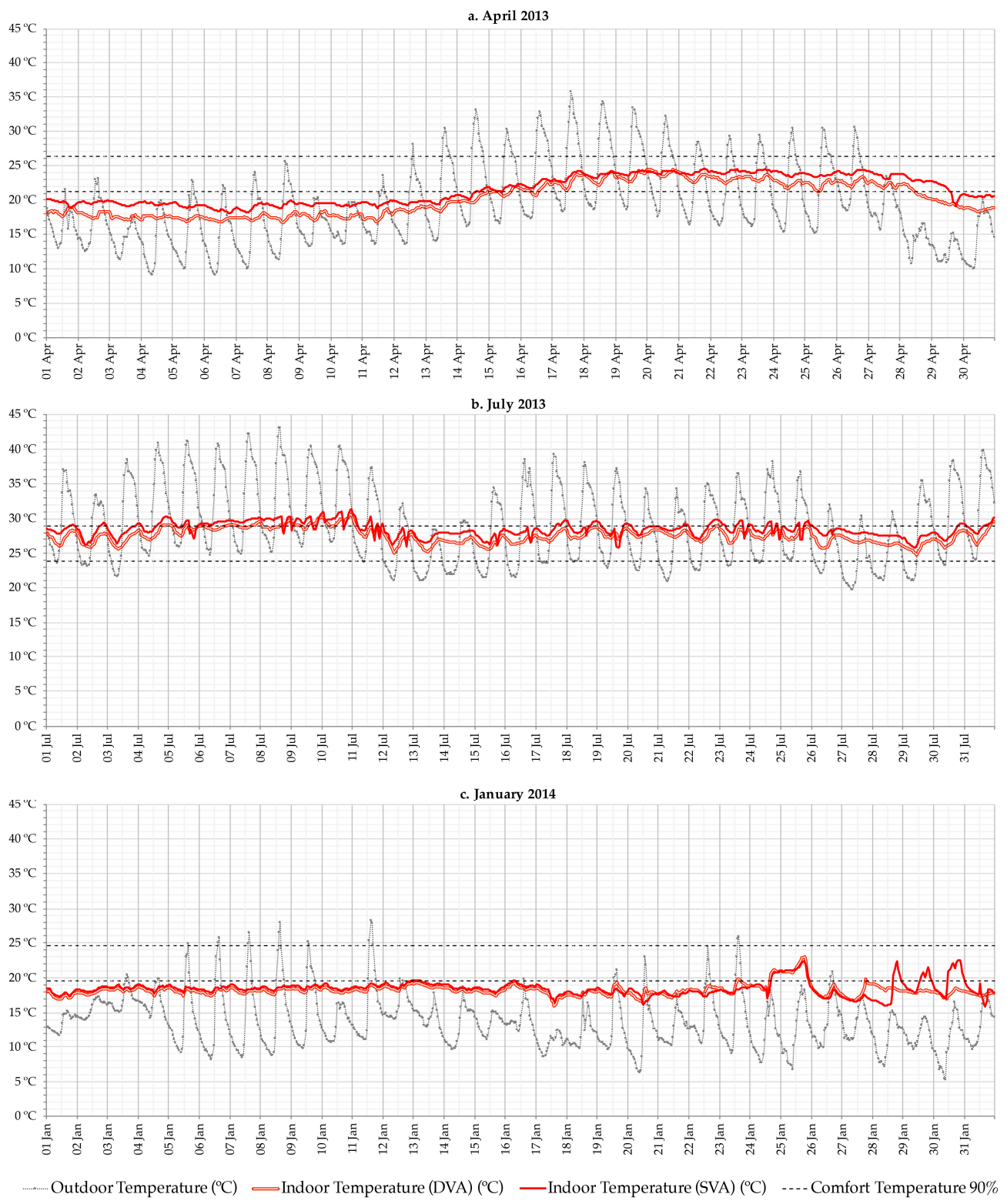

Figure 9. Monthly record of indoor temperature values in the monitored rooms of Dwelling A. 
In April, the differences between outdoor maximum and minimum temperature values fluctuated by up to $17.55{ }^{\circ} \mathrm{C}$ in the hottest day $\left(17\right.$ April; $\mathrm{T}_{\max } 35.8^{\circ} \mathrm{C}$, at $\left.14: 00\right)$, which contrasts to indoor conditions in Dwelling A, with an average indoor temperature of $22.5^{\circ} \mathrm{C}$ and a $2.4^{\circ} \mathrm{C}$ oscillation in bedroom DVA, as well as an average indoor temperature of $23.5^{\circ} \mathrm{C}$ and a $1.6^{\circ} \mathrm{C}$ oscillation in living-room SVA. For the day when the lowest temperature was reached ( $29 \mathrm{April} ; \mathrm{T}_{\min } 11^{\circ} \mathrm{C}$, at 11:00), outdoor temperature values fluctuated by up to $4{ }^{\circ} \mathrm{C}$, with an average indoor temperature of $19.5^{\circ} \mathrm{C}$ in bedroom DVA and a thermal variation of $1.3^{\circ} \mathrm{C}$, as well as an average indoor temperature of $21^{\circ} \mathrm{C}$ in living-room SVA and a thermal variation of $3.5^{\circ} \mathrm{C}$ (Figure 9a).

In July, whereas outdoor thermal oscillations reached $17^{\circ} \mathrm{C}$ on the hottest day (8 July; $\mathrm{T}_{\max }$ $43.1^{\circ} \mathrm{C}$, at 14:00), the indoor temperature only varied by up to $1.5^{\circ} \mathrm{C}$ in bedroom DVA and up to $2.5^{\circ} \mathrm{C}$ in living-room SVA, with a range of temperatures between $28^{\circ} \mathrm{C}$ and $30^{\circ} \mathrm{C}$ (Figure $9 \mathrm{~b}$ ). In the graph depicting the summer month, unusual jumps in the values are seen in the living-room SVA indoor conditions, especially when outdoor temperatures have been higher: on $5 \mathrm{July}$, when $\mathrm{T}_{\max }$ of $41.5^{\circ} \mathrm{C}$ was registered; from 8 (the hottest day of the month, $\mathrm{T}_{\max } 43.1^{\circ} \mathrm{C}$ ) to $12 \mathrm{July}$; from $15-19 \mathrm{July}$, when a $\mathrm{T}_{\max }$ value of $39.3^{\circ} \mathrm{C}$ was registered for $17 \mathrm{July}$; and finally, in the period between 23 and 26 July, when $\mathrm{T}_{\max }$ values went up to $38.2^{\circ} \mathrm{C}$ on 24 July (Figure 9b). It should hence be stated that this thermal homogeneity has been obtained in free evolution thermal conditions, that is without any kind of cooling devices in the bedroom and with minimum use of those in the living-room.

In January, indoor temperature variations reflect the evolution of outdoor temperatures. Thus, the day on which outdoor temperature values reached the lowest value $\left(20\right.$ January; $\mathrm{T}_{\min } 6.3^{\circ} \mathrm{C}$, at 21:00), indoor thermal oscillations went up by up to $2.5^{\circ} \mathrm{C}$ in both rooms, with an indoor temperature range between $16^{\circ} \mathrm{C}$ and $18{ }^{\circ} \mathrm{C}$, that is within the comfort band limits. Due to the lack of centralized heating, the user has had to sporadically turn on electric radiators on the coldest days of January. This conclusion can be drawn from the sharp changes in the registered indoor temperature values, mainly on 24 and 25 January, and from 28-30 of the same month (Figure 9c).

The data record for April show that, for a large number of hours, indoor temperature values in the monitored rooms have remained very near the comfort band limits $\left(21.3^{\circ} \mathrm{C}-26.3^{\circ} \mathrm{C}\right)$, according to those obtained by ASHRAE's adaptive comfort method [34] (Figure 9a). From April onwards and during the whole summer season, indoor temperature values rise significantly and even reach $30^{\circ} \mathrm{C}$, although they remain within the comfort range for most of the day, in accordance with the limits obtained for the summer season and specifically the month of July in this case $\left(23.9^{\circ} \mathrm{C}-28.9^{\circ} \mathrm{C}\right)[34]$ (Figure 9b).

However, the data record for January show that indoor temperature values have remained below winter comfort limits $\left(19.6{ }^{\circ} \mathrm{C}-24.6{ }^{\circ} \mathrm{C}\right)$ [34] most of the time, with temperature values that provoke uncomfortable conditions for the user (Figure 9c). This inability to preserve adequate comfort conditions, mainly due to the lack of basic services that would help the housing unit fight against indoor thermal loads, leads to the "energy poverty" concept, which remains a major issue to be solved by the energy retrofitting of residential buildings in the Mediterranean area [9,10,34].

\subsection{Indoor and Outdoor Temperature Variation}

Thermal behavior in dwellings and the way they respond to outdoor temperature variations have been represented by the difference between outdoor and indoor temperature values, on an hourly basis, for a representative day, in each of the three seasons studied. In this sense, thermal gains and losses related to outdoor thermal variations are identified, and therefore, the parts of the day in which these variations take place are also identified.

Three representative days of each month under study have been analyzed, which are in the order 17 April, 8 July 2013 and 20 January 2014 (Figure 10), when the outdoor temperature reached the maximum value of $43.10^{\circ} \mathrm{C}$ on 8 July and the minimum value of $6.3^{\circ} \mathrm{C}$ on 20 January. 

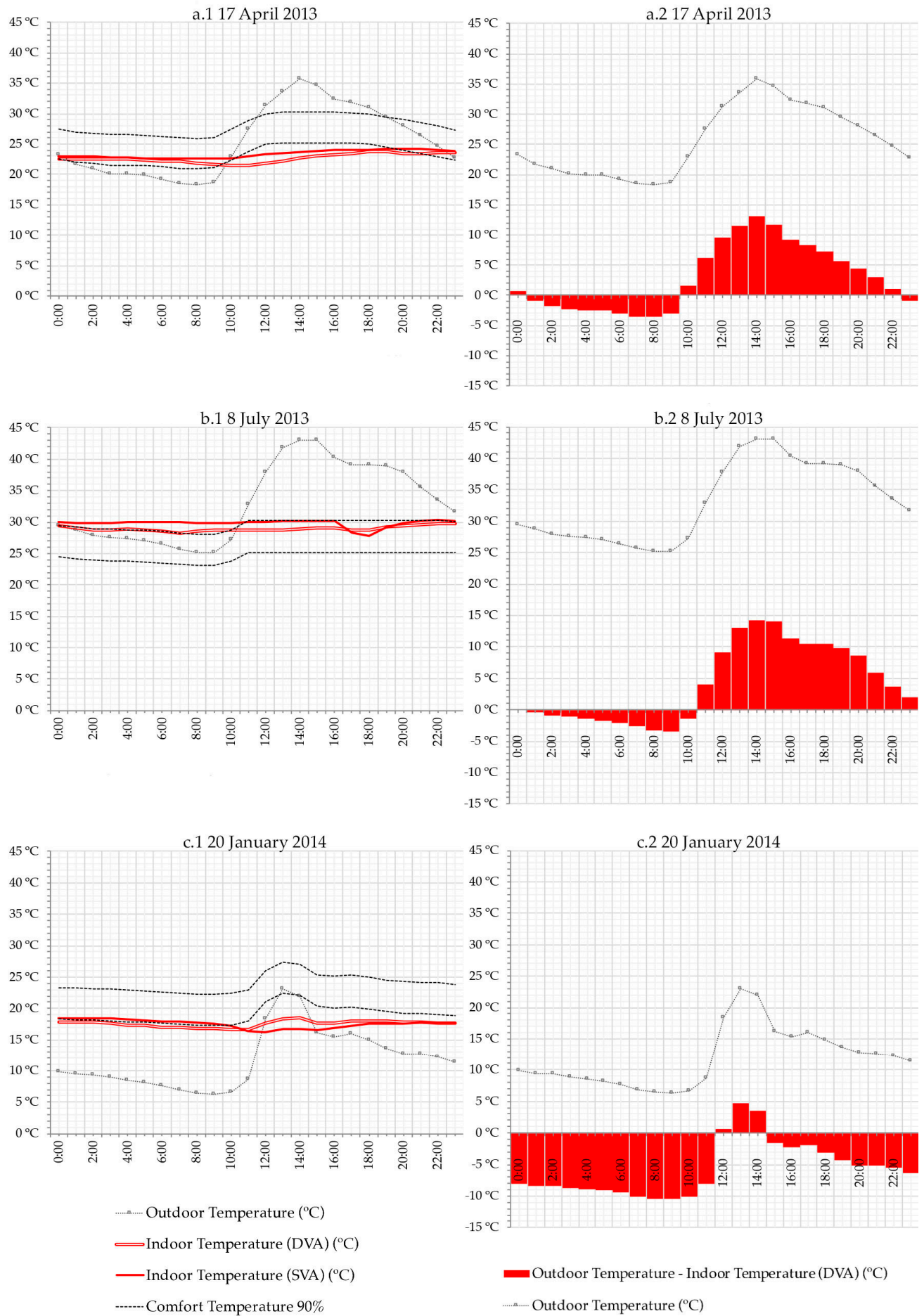

Figure 10. Temperature record in the monitored rooms of Dwelling A: (left) thermal evolution; (right) bedroom energy balance.

On 17 April, the dwelling presents many indoor thermal variations, with cooling or heating processes associated with outdoor temperature variations (Figure 10a.1) and a well-balanced indoor-outdoor environment (Figure 10a.2).

On a representative summer day, on 8 July, a maximum outdoor temperature value of $43^{\circ} \mathrm{C}$ is reached and an outdoor thermal fluctuation of $18{ }^{\circ} \mathrm{C}$ (Figure 10b.1). The evolution of the indoor temperature during the day shows an energy dissipation period during night hours, as well as high 
energy gains in daylight hours (Figure 10b.2). This fact indicates the need for adequate ventilation at night, which would help dissipate the energy accumulated during daylight hours and would thereby prevent indoor overheating situations from being produced by long periods of high temperatures.

Finally, the evolution of the outdoor temperature on 20 January, a representative day in winter, shows a thermal outdoor oscillation of $17^{\circ} \mathrm{C}$ (Figure 10c.1), while the indoor thermal evolution experiences mainly energy losses, due to such low outdoor temperatures (Figure 10c.2).

\subsection{Relative Humidity}

Regarding relative humidity, a similar tendency is shown during the winter and mid-season months, when indoor relative humidity values can stray outside the comfort limit values $(40 \%-60 \%)$, with slightly high daily fluctuations of $10 \%$, but show a growing tendency in line with that of the outdoor values. In contrast, outdoor measured relative humidity shows values close to $100 \%$ and much sharper daily oscillations of $30 \%-40 \%$ (Figure 11 ).
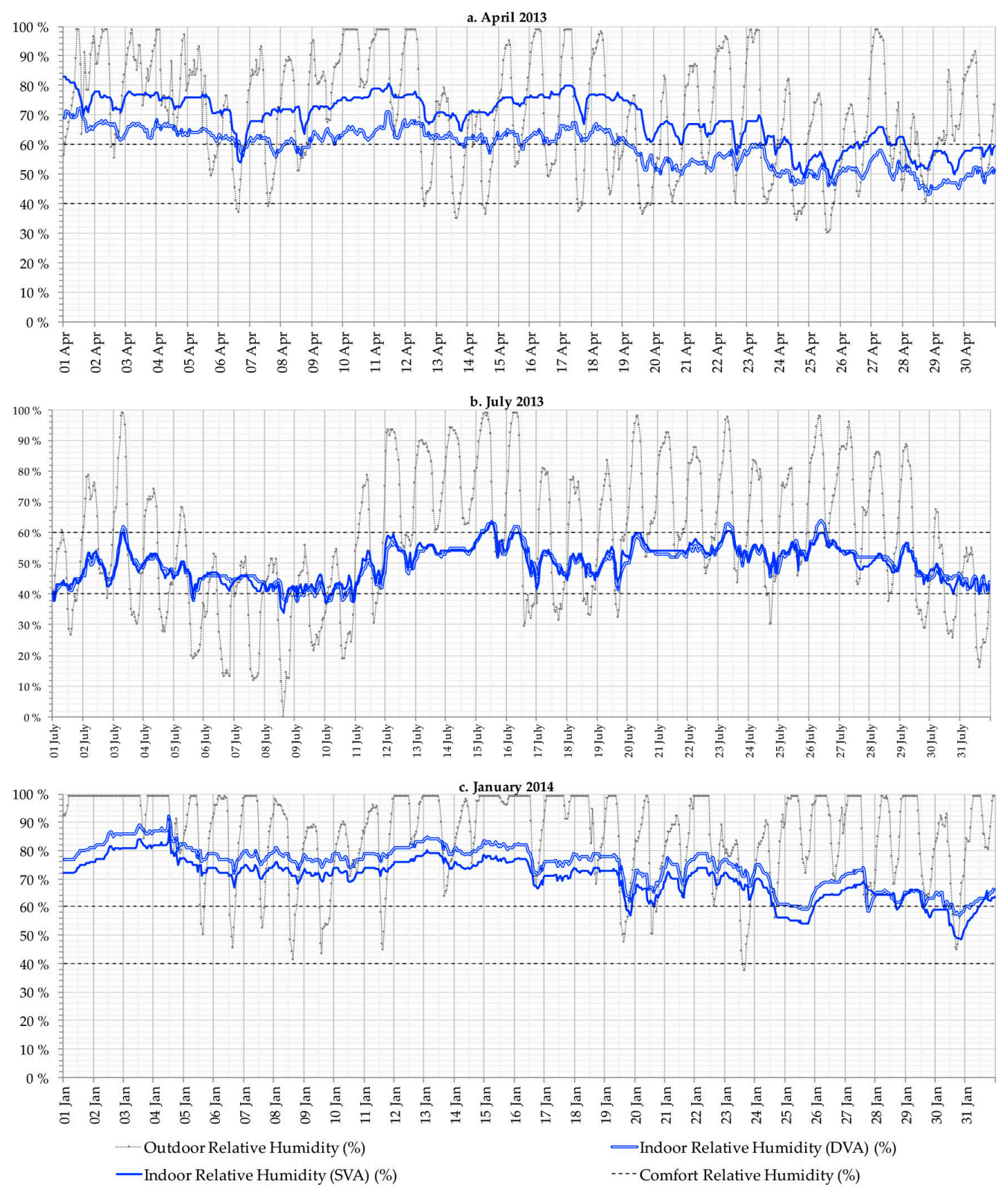

Figure 11. Monthly record of indoor relative humidity in the monitored rooms of Dwelling A. 
The evolution of indoor relative humidity during mid-season months (spring: March, April and May; autumn: September, October and November) indicates that the windows of the dwelling have been opened. In the beginning of April, when more rainfall periods with low temperatures and high relative humidity values close to $100 \%$ take place, recorded values indoors are equally elevated, reaching from $50 \%-70 \%$ (Figure 11a). This illustrates that opening the windows during mid-season months is fairly important, with the aim of fighting against large fluctuations in hygrothermal values in the B4 climate zone.

In contrast, the summer results for relative humidity show evidence of two facts (Figure 11b). On the one hand, there is the use of night ventilation by opening the windows during night hours, thereby leading relative humidity to tend towards outdoor values. On the other hand and in fact due to high outdoor temperatures, the use of cooling devices during daylight hours is also demonstrated in the decrease of indoor relative humidity values, since windows remain closed and cooling devices reduce the level of air humidity. Hence, the importance of night energy dissipation and that of ventilation is demonstrated yet again.

\section{Conclusions}

The dwellings in this case-study are overheated, with little or no thermal dissipations due to the lack of night cooling, which makes it difficult to reach adequate comfort conditions for the users. In summer, outdoor daylight temperatures are very high with sharp decreases of between $15{ }^{\circ} \mathrm{C}$ and $20^{\circ} \mathrm{C}$ during the night hours. However, indoor temperatures remain elevated, which shows stable behavior, with thermal fluctuations of between $0.5^{\circ} \mathrm{C}$ and $2.5^{\circ} \mathrm{C}$ during the day and a slight decrease in indoor temperatures at night. South and southeast orientations, with major thermal gains due to heating from direct sunlight, together with inadequate ventilation, which is limited to the user's decision to open the window, provide the reason for this behavior, with a clear impact on the energy balance of the dwelling.

During the winter period, outdoor temperatures decrease by between $5{ }^{\circ} \mathrm{C}$ and $10{ }^{\circ} \mathrm{C}$, with an irregular daily fluctuation, and hence, major rises and falls of $19^{\circ} \mathrm{C}$, which counteract the others of $11^{\circ} \mathrm{C}$ or even $4{ }^{\circ} \mathrm{C}$, can be found on many occasions. The indoor temperature maintains a regular tendency, with thermal oscillations of, in general, between $1.5^{\circ} \mathrm{C}$ and $3{ }^{\circ} \mathrm{C}$, due to outdoor thermal variations. These indoor temperature values in turn lie below acceptable comfort limit values, since sunlight hours in this season fail to achieve sufficient energy gains to maintain the conditions of well-being for the users.

This fact, together with the lack of indoor thermal supplies and the high levels of energy waste that inefficient cooling or heating systems may suppose when fighting thermal loads in winter, as well as in summer constitute the reasons why indoor comfort rarely exists, as well as why "energy poverty" situations commonly arise in the Mediterranean housing stock.

Monitoring environmental parameters enables the real passive energy behavior to be ascertained of residential stock, whose habitability conditions, mainly in summer and winter periods, remain far from the present comfort standards. This monitoring brings to light the difficulty involved in the control of energy balance and in indoor air renovation due to uncontrolled air infiltrations and the user's performance in opening windows to take advantage of natural ventilation. The energy assessment and analysis of its current state and under its conditions of use constitute a major step to be carried out before the accomplishment of a retrofitting action, in order to improve energy efficiency and comfort conditions, which would allow the social returns obtained to be measured.

According to the results, some retrofit solutions are hereby enumerated, which must be first separately analyzed in a further research in order to choose one or another: an increase in thermal isolation in the opaque part (i.e., ETICS; ventilated facade; although in this case, the latter should be rejected because of heritage protection of the outer walls aesthetics), as well as in the openings (i.e., double glazing and window frames with thermal bridge breaking); an increase in the thermal inertia of the building and a controlled mechanical ventilation system (CMV system). 
The deficiencies in the energy and environmental performance of these multi-family housing buildings should be addressed promoting passive cooling strategies in summer, which is particularly relevant in the Mediterranean area, especially heat dissipation during night hours (night ventilation); moreover, shading devices and solar protections combined with solar-control glazing could also be efficient in southern orientations (south, southeast and southwest).

Existing housing stock from the Mediterranean area shows great potential for improvement, as these kinds of interventions may suppose only a minor economic impact, but they will certainly have a significant effect on the energy performance of the building.

Author Contributions: R.S. and J.J.S.S. conceived and designed the experiments; T.B.d.P. performed the experiments; T.B.d.P., R.S. and J.J.S.S. analyzed the data and results, organized the structure of the paper and wrote it; R.S. and J.J.S.S. revised the final manuscript for subscription.

Conflicts of Interest: The authors declare no conflict of interest.

\section{References}

1. Instituto para la Diversificación y Ahorro de la Energía (IDEA). SECH-SPAHOUSEC Project: Analysis of the Energy Consumption in the Spanish Households. Available online: http://www.idae.es/uploads/ documentos/documentos_informe_spahousec_acc_f68291a3.pdf (accessed on 2 September 2016).

2. Spanish Royal Decree RD 2429/1979. Available online: http://www.boe.es/boe/dias/1979/10/22/pdfs/ A24524--24550.pdf (accessed on 2 September 2016).

3. European Parliament and Council. Directive 2012/27/EU on Energy Efficiency, Amending Directives 2009/125/EC and 2010/30/EU and Repealing Directives 2004/8/EC and 2006/32/EC; European Parliament and Council: Brusels, Belgium, 2012.

4. Cortes Generales. Ley 8/2013 de Rehabilitación, Regeneración y Renovación Urbanas; Boletín Oficial del Estado: Madrid, Spain, 2013.

5. Cuerda, E.; Pérez, M.; Neila, J. Facade Typologies as a Tool for Selecting Refurbishment Measures for the Spanish Residential Building Stock. Energy Build. 2014, 76, 119-129. [CrossRef]

6. Dascalaki, E.G.; Droutsa, K.G.; Balaras, C.A.; Kontoyiannidis, S. Building Typologies as a Tool for Assessing the Energy Performance of Residential Buildings—A Case Study for the Hellenic Building Stock. Energy Build. 2011, 43, 3400-3409. [CrossRef]

7. Episcope. EEI-TABULA Project. Typology Approach for Building Stock Energy Assessment. Available online: http://episcope.eu/iee-project/tabula/ (accessed on 23 October 2016).

8. De Luxán, M.; Gómez, G. Dos bloques de viviendas y locales comerciales en San Cristóbal de los Ángeles, Madrid. Inf. Constr. 2006, 58, 5-16.

9. Leth-Petersen, S.; Togeby, M. Demand for space heating in apartment blocks: measuring effects of policy measures aiming at reducing energy consumption. Energy Econ. 2001, 23, 387-403. [CrossRef]

10. Galvin, R.; Sunikka-Blank, M. Economic Viability in Thermal Retrofit Policies: Learning from Ten Years of Experience in Germany. Energy Policy 2013, 54, 343-351. [CrossRef]

11. Hens, H.; Janssens, A.; Depraetere, W.; Carmeliet, J.; Lecompte, J. Brick Cavity Walls: A performance analysis based on measurements and simulations. J. Build. Phys. 2007, 31, 95-124. [CrossRef]

12. Jakob, M. Marginal costs and co-benefits of energy efficiency investments. The case of the Swiss residential sector. Energy Policy 2006, 34, 172-187. [CrossRef]

13. Salmerón, J.M.; Álvarez, S.; Molina, J.L.; Ruiz, A.; Sánchez, F.J. Tightening the energy consumptions of buildings depending on their typology and on Climate Severity Indexes. Energy Build. 2013, 58, 372-377. [CrossRef]

14. Mihalakakou, G.; Santamouris, M.; Tsangrassoulis, A. On the energy consumption in residential buildings. Energy Build. 2002, 37, 727-736. [CrossRef]

15. Santamouris, M.; Kolokotsa, D. Passive cooling dissipation techniques for buildings and other structures: The state of the art. Energy Build. 2013, 57, 74-94. [CrossRef]

16. Dall'O, G.; Sarto, L.; Galante, A.; Pasetti, G. Comparison between predicted and actual energy performance for winter heating in high-performance residential buildings in the Lombardy region (Italy). Energy Build. 2012, 47, 247-253. [CrossRef] 
17. D'Ambrosio, F.R.; Dell'Isola, M.; Palella, B.I.; Riccio, G.; Russi, A. On the measurement of the mean radiant temperature and its influence on the indoor thermal environmental assessment. Build. Environ. 2013, 63, 78-88.

18. Santamouris, M.; Alevizos, S.M.; Aslanoglou, L.; Mantzios, D.; Milonas, P.; Sarelli, I.; Karatasou, S.; Cartalis, K.; Paravantis, J.A. Freezing the Poor-Indoor environmental quality in low and very low income households during the winter period in Athens. Energy Build. 2014, 70, 61-70. [CrossRef]

19. Földváry, V.; Pustayová, H.; Petrás, D. Analysis of energy performance and indoor climate conditions of the Slovak housing stock before and after its renovation. Energy Procedia 2015, 78, 2184-2189. [CrossRef]

20. AICIA-Grupo de Termotecnia de la Escuela Superior de Ingenieros Industriales de la Universidad de Sevilla. Escala de Calificación Energética para Edificios de Nueva Construcción; IDAE: Madrid, Spain, 2009.

21. Sendra, J.J.; Domínguez-Amarillo, S.; Bustamante, P.; León, A.L. Energy intervention in the residential sector in the south of Spain: Current challenges. Inf. Constr. 2013, 65, 457-464. [CrossRef]

22. Raftery, P.; Keane, M.; Costa, A. Calibrating whole building energy models: Detailed case study using hourly measured data. Energy Build. 2011, 43, 3666-3679. [CrossRef]

23. Blázquez, T.; Suárez, R.; Sendra, J.J. Towards a calibration of building energy models: A case study from the Spanish housing stock in the Mediterranean climate. Inf. Constr. 2015, 67, e128.

24. Royapoor, M.; Roskilly, R. Building model calibration using energy and environmental data. Energy Build. 2015, 94, 109-120. [CrossRef]

25. Fundación Docomomo Ibérico. Conjunto de Viviendas La Estrella. Available online: http:/ / www.docomomoiberico.com/index.php?option=com_k2\&view=item\&id=1008:conjunto-de-viviendasla-estrella\&Itemid=11\&vista=1\&lang=es (accessed on 2 September 2016).

26. Andalusian Building Heritage Institute (IAPH). Conjunto de Viviendas La Estrella. Available online: http:/ / www.iaph.es/patrimonio-inmueble-andalucia/resumen.do?id=i17217 (accessed on 2 September 2016).

27. Construction Elements Catalogue (CTE-WEB). Available online: http://cte-web.iccl.es (accessed on 18 October 2016).

28. Ministerio de Vivienda. Código Técnico de la Edificación (CTE) Documento Básico de Ahorro de Energía. 2013. Available online: http://www.codigotecnico.org/images/stories/pdf/ahorroEnergia/DBHE.pdf (accessed on 2 September 2016).

29. León, A.L.; Muñoz, S.; León, J.; Bustamante, P. Monitoring environmental and energy variables in the construction of subsidized housing: Cros-Pirotecnia building in Sevilla. Inf. Constr. 2010, 62, 67-82. [CrossRef]

30. ISO 7726:1998. Ergonomics of the Thermal Environment_-Instruments for Measuring Physical Quantities, 2nd ed.; International Organization for Standardization: Geneva, Switzerland, 1998.

31. (ISO 9972:1996, Modified) ISO 9972:2015. Thermal Performance of Buildings_Determination of Air Permeability of Buildings_Fan pressurization Method, 3rd ed.; International Organization for Standardization: Geneva, Switzerland, 2015.

32. Ferrari, S.; Zanotto, V. Adaptive Comfort: analysis and application of the main indices. Build. Environ. 2012, 49, 25-32. [CrossRef]

33. American Society of Heating, Refrigerating and Air-Conditioning (ASHRAE). Spanish Weather for Energy Calculations (SWEC Weather Files). Available online: https:/ /energyplus.net/weather-location/europe_ wmo_region_6/ESP//ESP_Sevilla.083910_SWEC (accessed on 2 September 2016).

34. Proyecto EPEE: European Fuel Poverty and Energy Efficiency. Evaluation of Fuel Poverty in Partners' Country. National Analysis. Spain. Available online: http://www.powerhouseeurope.eu/uploads/tx_ phecasestudies/Case_Studies_epee_4_2._ES_pdf.pdf (accessed on 2 September 2016).

(C) 2016 by the authors; licensee MDPI, Basel, Switzerland. This article is an open access article distributed under the terms and conditions of the Creative Commons Attribution (CC-BY) license (http://creativecommons.org/licenses/by/4.0/). 